\title{
FLIGHTS OF THE ANT POLYERGUS LUCIDUS MAYR*
}

\author{
By Mary Talbot
}

\author{
Lindenwood College, St. Charles, Missouri
}

Flights of ants at the Edwin S. George Reserve, Livingston County, Michigan, have been studied over a number of years (Talbot 1956, I959, I963, 1964, I966, and Kannowski 1959a, I959b). This paper is another in the flight series and concerns the slave-making ant, Polyergus lucidus Mayr.

Polyergus colonies are scattered over the George Reserve, living in open fields or at woods' edge and forming mixed colonies with Formica pallidefulva nitidiventris Emery. The flights recorded here took place mainly from the Lawn Colony, where 26 flights were seen during 1960, I961, and 1962. These observations were supplemented, for comparison, by records of seven flights from two other colonies.

The main flights of Polyergus at the Reserve took place during August. They began in late July and extended into early or midSeptember. July 3I, I962 was the date of the earliest flight seen, although a dealate female was found on July 28 , 1964. The latest flight recorded, on September 9, 1963, liberated only three males. The flight season at any one colony is long, probably a month to six weeks, and the time of starting and stopping flights must vary considerably from colony to colony, depending on local environment of the nest and rate of maturing of the brood.

Polyergus spread the maturing of brood of winged ants over an extended period, and flights began long before all of the adults had emerged. Winged pupae have been found as early in the year as June I9, 1962, and as late as September I, 1964. The earliest time that adult winged ants were found was July 2 I, I962, and there were still some in the nest on September 9, 1963, when the latest observations were made.

The total number of males and females produced could not be determined because not all of the flights of a year were seen. One medium-sized colony that was dug and counted still had i I 5 females, 407 males, and 13 male pupae on September I, 1965. Eight flights of

*The work was assisted by a grant from the United States National Science Foundation. Facilities of the University of Michigan's Edwin S. George Reserve were made available by Dr. Francis C. Evans, Associate Director, and Dr. T. H. Hubbel, Director of the Reserve.

Manuscript received by the editor November 27, 1967 
the Lawn Colony, recorded in 196r, yielded a total of 58 females and 8I4 males. The largest flight seen at this nest, August I8, I96I, liberated i 7 females and 335 males.

Polyergus flights were distinguished by several outstanding characteristics. They took place in early afternoon at very high temperatures. They required bright light and were delayed or prevented by any cloud that came over the nest. Gusts of wind stimulated flying. Males executed a kind of "dance" as they ran up and down grass blades and over and around each other before they seemed ready to fly.

Time of day. Flights took place in the early afternoon and did not vary greatly in time of day. At the Lawn Colony males might come out and begin climbing grasses as early as I2:3 I PM (E.S.T.) or as late as 2:IO PM, but the usual time was about I PM. Flying might begin anywhere from three to 60 minutes later, the mean time for 2I flights being I:I6 PM. The two other colonies had a slightly later time pattern. At the Hidden Valley nest alates began flying at about I :45 PM and the 0-26 Colony was even later, with $2: \mathrm{OI} \mathrm{PM}$ as its mean time.

Temperature. All flights took place at high temperatures. On one occasion males began to climb grasses at $77^{\circ} \mathrm{F}^{*}$, and the first flew at $78^{\circ} \mathrm{F}$; but for all other flights the temperature was $80^{\circ} \mathrm{F}$ or more. Temperatures between $85^{\circ} \mathrm{F}$ and $90^{\circ} \mathrm{F}$ were especially favorable. Above $90^{\circ} \mathrm{F}$ ants climbed grasses quickly, and males were especially active in their "dance." The Hidden Valley Colony had two flights at $96^{\circ} \mathrm{F}$ and $97^{\circ} \mathrm{F}$; but at these high temperatures females could not run about on the ground as they usually did, and even on grasses they moved rapidly and flew quickly. Flights were not triggered by any certain temperature, for favorable temperatures were sometimes reached several hours before flights began.

Light. Flights occurred when the sun was almost directly overhead; and direct, bright light seemed essential. Any light above 7,000 foot-candles was favorable, and the Hidden Valley ants flew in the brightest light recorded ( IO,OOO ft-c). Sparse flying could take place at light as low as 4,000 $\mathrm{ft}-\mathrm{c}$, and a few ants flew in even dimmer light. Cutting down of light by flickering shade of moving tree branches was tolerated rather well, but the more solid shade of clouds was not tolerated. Moving clouds could prevent or interrupt a flight. Although temperatures stayed between $87^{\circ} \mathrm{F}$ and $82^{\circ} \mathrm{F}$ on August 16, 1962, there was no flight because frequent fluffy white

\footnotetext{
*Temperature recorded 10 inches above the ground.
} 
clouds kept alternating the light from as high as 9,200 $\mathrm{ft}-\mathrm{c}$ to as low as 3,400 ft-c. A few males kept coming up on grasses and going down again, but they never had time between clouds for the running about which precedes flying. On August 28, 1962, after 4I males had flown and ten males were up in an actively moving group, a cloud reduced light from 7,400 ft-c to 2,300 ft-c. They all stood still until it passed. Soon after, when another cloud brought light down to $2,200 \mathrm{ft}-\mathrm{c}$, they walked down and into the entrance, only to come up again when the cloud passed and the light brightened to $4,200 \mathrm{ft}-\mathrm{c}$.

Wind. Polyergus flights were not prevented by any wind recorded. Breezes up to four to six miles per hour seemed to encourage male activity. An eight to eleven mph wind might make them stop moving and hold on, but it also stimulated the take-off into flight. Once, a record number of approximately 60 males flew upward with a IO-mph gust.

Typical fight activity. During the flight season single males and females often started coming into sight down in the nest entrance at about the time that $F$. p. nitidiventris workers began foraging in the morning ( $8: 30-9: 30$ on warm mornings). From then on, every few minutes one or two would approach the surface and then retreat abruptly. By midday a group of male heads could be seen down in the entrance; and later, as the sun shone into the entrance, they would begin coming to the surface. At first one or two males would climb quickly onto grasses and then retreat as quickly. Soon some would stay, and a little mass of males would accumulate on the grasses above the nest. These would all be involved in a great activity, running up and down grasses and bumping into and running over each other in what seemed like a frenzied dance. In a few minutes there might be 50 to 150 males taking part in the movement; then, one by one, individuals would flutter wings and fly. Usually flying was rather sparse, with one to I 5 males flying a minute; but the mass on grasses never stopped their jerky running, so there was always an impression of great activity. Some males did not take off well on their first few tries but instead flew and dropped to neighboring grasses, causing the flying area to increase in size. As many flew, the group on grasses lessened, activity slowed, and one by one the last stragglers took off. On days when only a few males emerged and flew there could be no interacting group, but each male would still run up and down grasses for several minutes before flying.

Females acted quite differently. Although one or two might come out and then duck back at any time during the morning, they did 


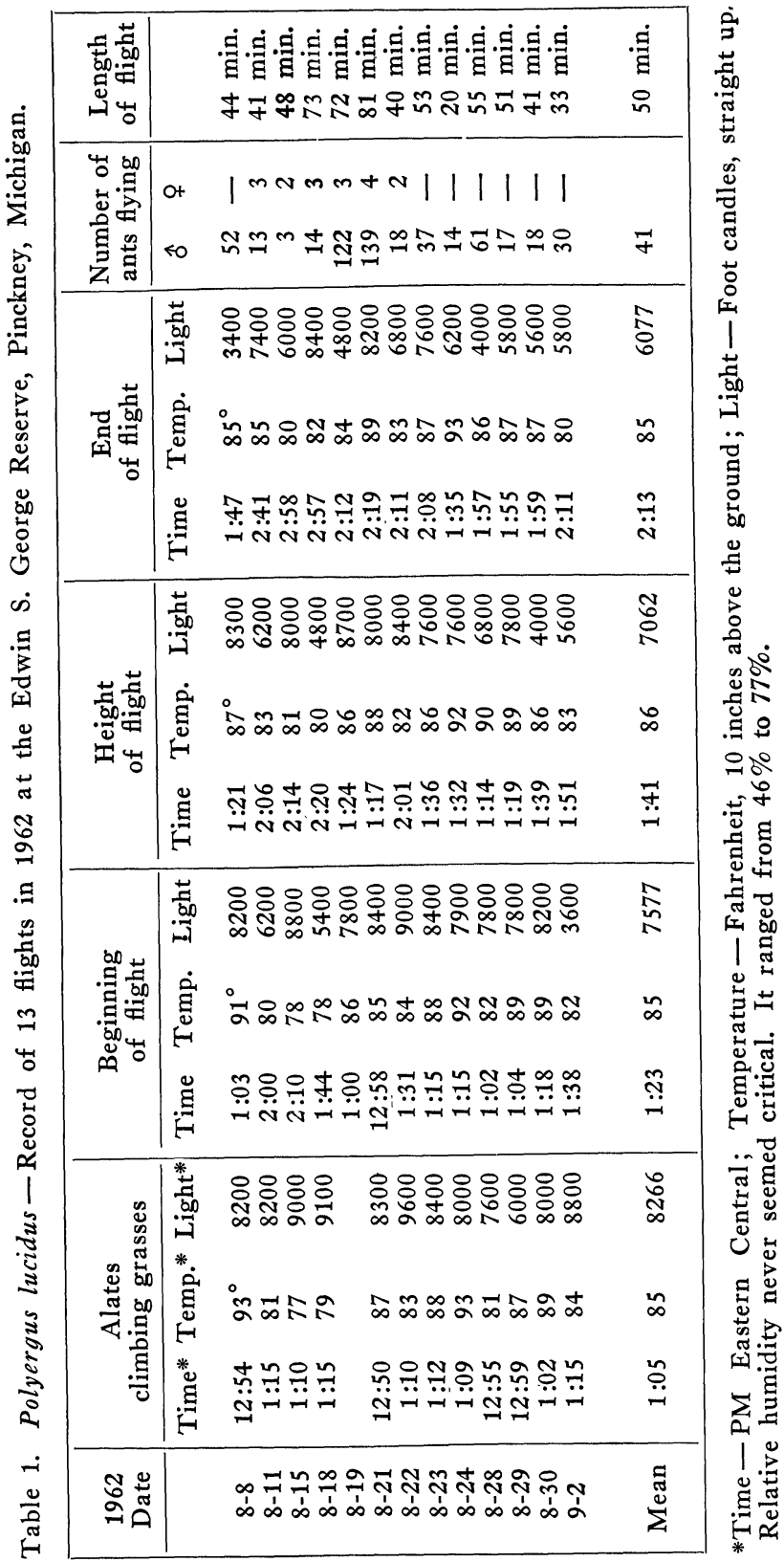


not begin to move away from the structure until male flight had been going on for from 5 to 20 minutes. The females came out singly, and there were never many in sight at one time (I-9). A female would emerge, walk or run on the ground near the nest area, and climb up and down grasses, sometimes standing for a long time on a grass tip. After several minutes of this, she would climb a grass stem, flutter her wings, and fly. Often the first take-off was not successful; she would drop to a neighboring grass, and the wandering would begin again. This more leisurely action on the part of females sometimes prolonged flights for as much as eight to 28 minutes after all males had flown. The Lawn Colony did not produce many females; 58 were counted in three flights in $196 \mathrm{I}$ and $\mathrm{I} 7$ in six flights in 1962. On these nine flights the time of flying of the first female was delayed beyond that of the first male by 16 to $5 \mathrm{I}$ minutes, with a mean of 36 minutes. The delay on the part of the females could not be accounted for on the basis of changes in temperature or light since the mean starting temperature and light for males were $83.3^{\circ} \mathrm{F}$ and 7,478 ft-c while for females they were $83.5^{\circ} \mathrm{F}$ and $7,288 \mathrm{ft}$-c.

Workers played only a moderate role in flights. Polyergus workers did not react to the alates in any way and only occasionally did one come to the surface, to retreat again soon or to move out into the grasses. $F . p$. nitidiventris workers enlarged entrances at the beginning of the flight season and reopened them after rains. During good flying weather they foraged busily, paying no attention to the alates. But sometimes at the start of a flight a group of 10 to 20 workers would follow the first males up onto grasses and try to get them to turn back, or they would hunt for stragglers at the end of a flight. Occasionally, under adverse conditions, such as lessening light or very high ground temperatures, they would become active in the middle of a flight. Males were often carried down grasses into the nest. The larger females were sometimes carried, but more often they were simply nudged until they retreated.

Colony founding. Once a female has mated and discarded her wings, her next problem is to locate a Formica pallidefulva nitidiventris colony which she can invade. One method by which young, dealate females find such colonies was discovered while raids were being watched at the $0-26$ and the Lawn Nests. On 15 different days, during flight seasons, one or two dealate females were seen hanging about a Polyergus nest during the afternoon. The females circled in the grasses and frequently cut across the nest area. Polyergus workers, running about in preraid activity, were hostile and 
would try to bite any female encountered. On two different occasions one such female was seen to follow a raiding party to a $F$. $p$. nitidiventris nest, keeping just outside the column of ants. The first female was lost from view as she circled around the mass of ants entering the raided nest. The second, which had hung around the column edge, being bitten every time she got into a group, followed the raiding party for 43 minutes to a colony 213 feet away. At the raided nest she succeeded in getting down into the entrance three times but was pulled out each time by emerging Polyergus workers. It is not known if she finally got into the nest, but she did not return with the raiding ants.

This seems to be an excellent method of finding a colony to invade. The raiding ants not only lead a female directly to a colony but present her with one which is demoralized, depleted of brood, and probably saturated with Polyergus odor.

One incipient Polyergus colony was found on the Reserve. It consisted of a queen with a few pupae living in a small $F$. p. nitidiventris colony.

Contrasts in fights of POLYERGUS LUCIDUS and APHAENOGASTER TREATAE. Different species of ants show great variation in their flights - in time of year, time of day, and reaction to temperature, light, and wind. A comparison of Polyergus lucidus with Aphaenogaster treatae Forel is especially interesting because both live in open fields, and both have flights near midday when normally their workers are not above ground.

Polyergus alates flew in early afternoon, at high temperatures $\left(97^{\circ}-78^{\circ} \mathrm{F}\right)$, in bright light ( $\left.10,000-4,000 \mathrm{ft}-\mathrm{c}\right)$, while their workers raided later in the day $(3: 06-8: 14 \mathrm{PM})$, at lower temperatures $\left(9 \mathrm{I}^{\circ}-65^{\circ} \mathrm{F}\right)$ and less intense light $(6,300-26 \mathrm{oft}-\mathrm{c})$. Aphaenogaster treatae flights also occurred near midday and usually on bright days when temperatures were too high for workers to forage (above $\left.88^{\circ} \mathrm{F}\right)$. The contrast came from the fact that $A$. treatae could actually not fly under these extreme conditions, but waited until a passing cloud modified them briefly. Thus, they had a flight on one day when temperature was $9 \mathrm{I}^{\circ} \mathrm{F}$ and light $9,200 \mathrm{ft}-\mathrm{c}$ but they came out and flew only when a brief cloud reduced temperature to $85^{\circ} \mathrm{F}$ and light to $2,400 \mathrm{ft}$-c (Talbot I966). Such a cloud would have stopped a Polyergus flight. The two species also reacted differently to wind. Winds as low as $2 \mathrm{mph}$ caused $A$. treatae alates to retreat, while much higher winds stimulated Polyergus flying. 


\section{SUMMARY}

At the Edwin S. George Reserve, in southern Michigan, flights of the ant Polyergus lucidus took place in late July, August, and early September. They occurred in the early afternoon when temperatures were high $\left(97^{\circ}-78^{\circ} \mathrm{F}\right)$ and light bright (10,000-3,600 ft-c). Passing clouds could prevent or delay flights, but winds did not. Males formed very actively moving clusters on grasses before flying. Females came out singly and usually walked away from the nest before climbing and flying. Some dealate females found Formica pallidefulva nitidiventris colonies to invade by following raiding parties of Polyergus workers.

\section{KANNOWSKI, P. B.}

\section{REFERENCES}

1959. The flight activities of Dolichoderus (Hypoclinea) taschenbergi (Hymenoptera: Formicidae). Ann. Ent. Soc. Amer. 52 (6): 755-760.

1959. The flight activities and colony-founding behavior of bog ants in Southeastern Michigan. Insectes Sociaux 6: 115-162.

Talbot, Mary

1956. Flight activities of the ant Dolichoderus (Hypoclinea) mariae Forel. Psyche 63: 134-139.

1959. Flight activities of two species of ants of the genus Formica. Amer. Mid. Nat. 61: 124-132.

1963. Local distribution and flight activities of four species of ants of the genus Acanthomyops Mayr. Ecology 44: 549-557.

1964. Nest structure and flights of the ant Formica obscuriventris Mayr. Animal Behavior 12: 154-158.

1965. Populations of ants in a low field. Insectes Sociaux 12: 19-47.

1966. Flights of the ant Aphaenogaster treatae. Jour. Kansas Ent. Soc. 39: $67-77$.

1967. Slave raids of the ant, Polyergus lucidus Mayr. Psyche, 74: 299313. 

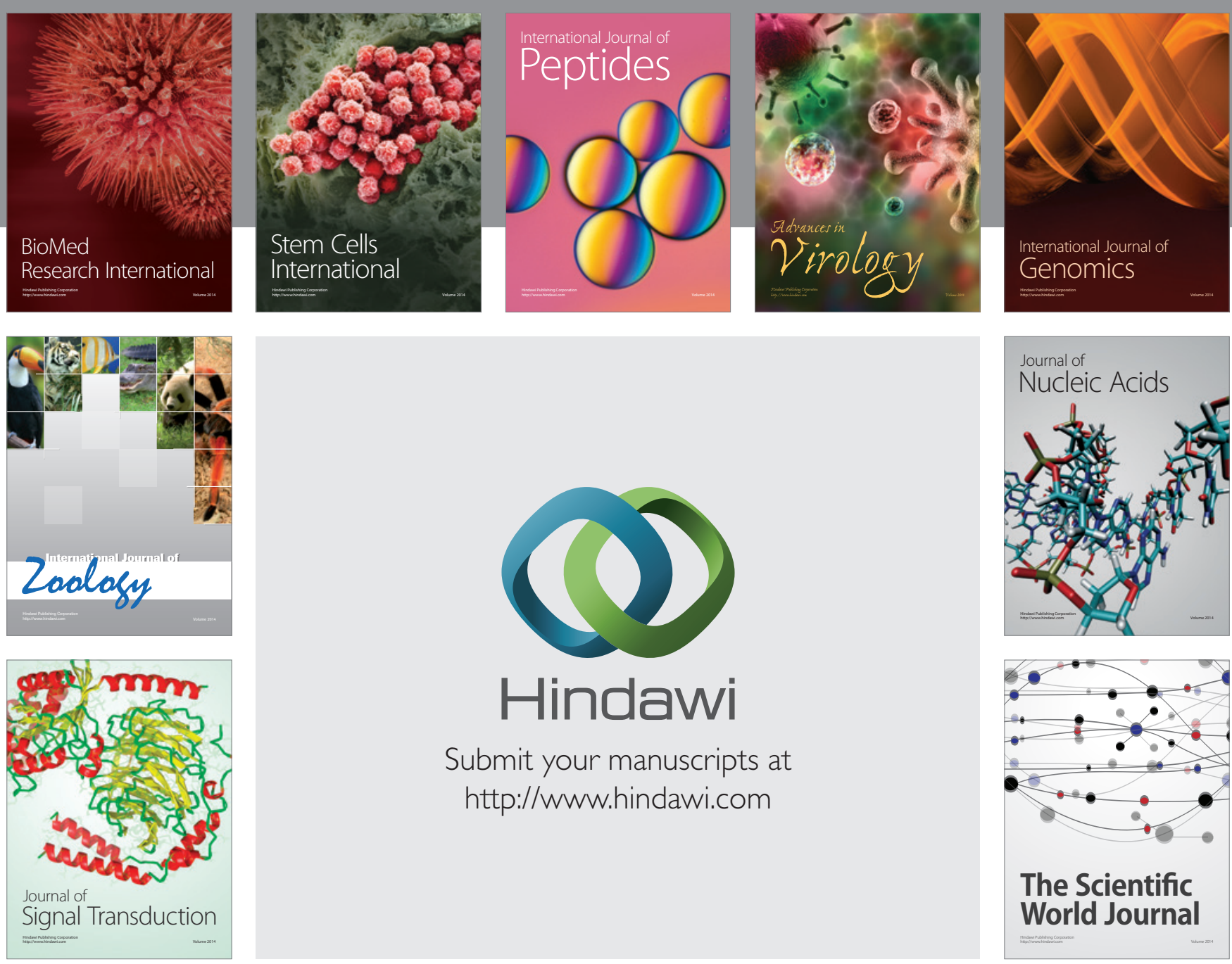

Submit your manuscripts at

http://www.hindawi.com
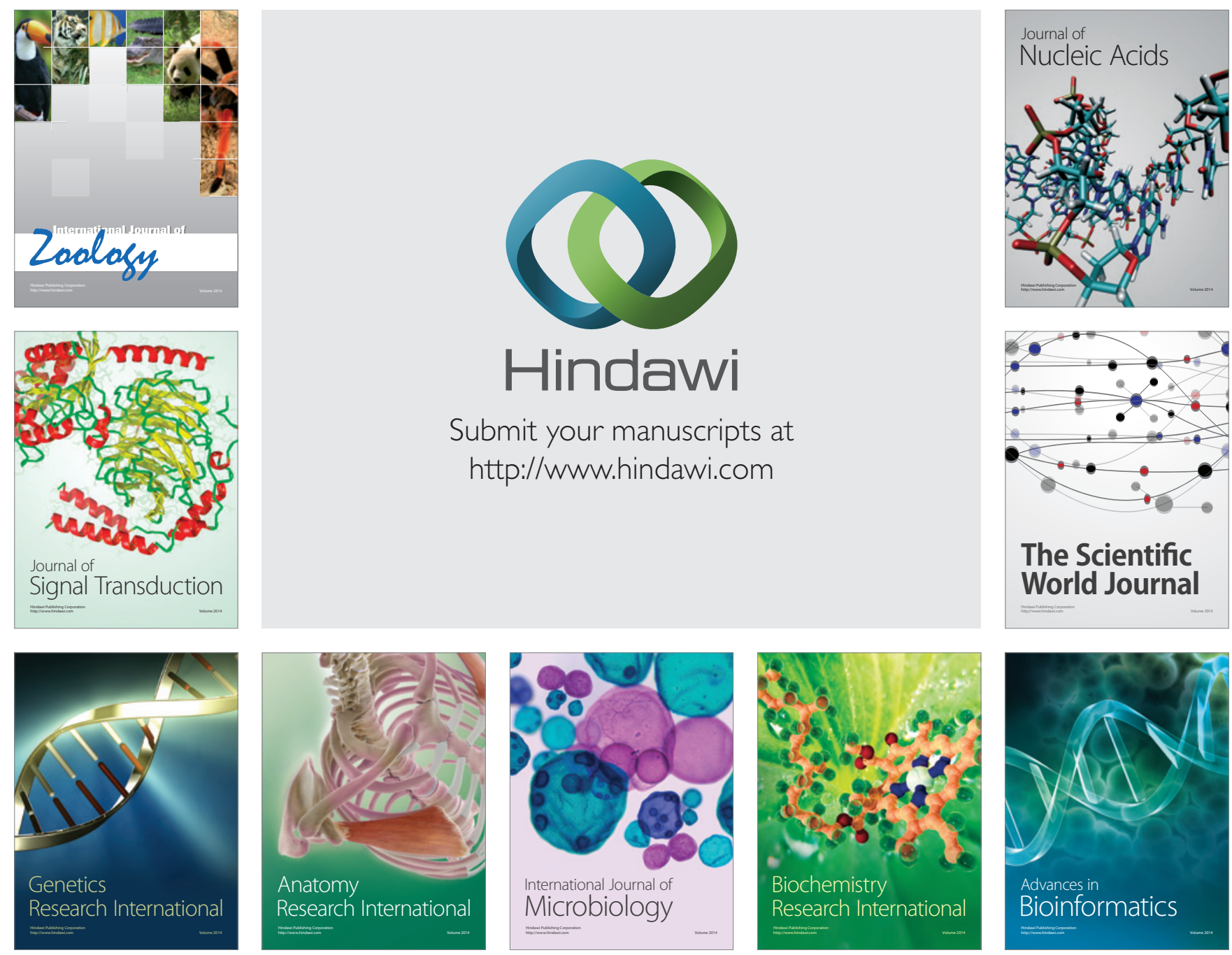

The Scientific World Journal
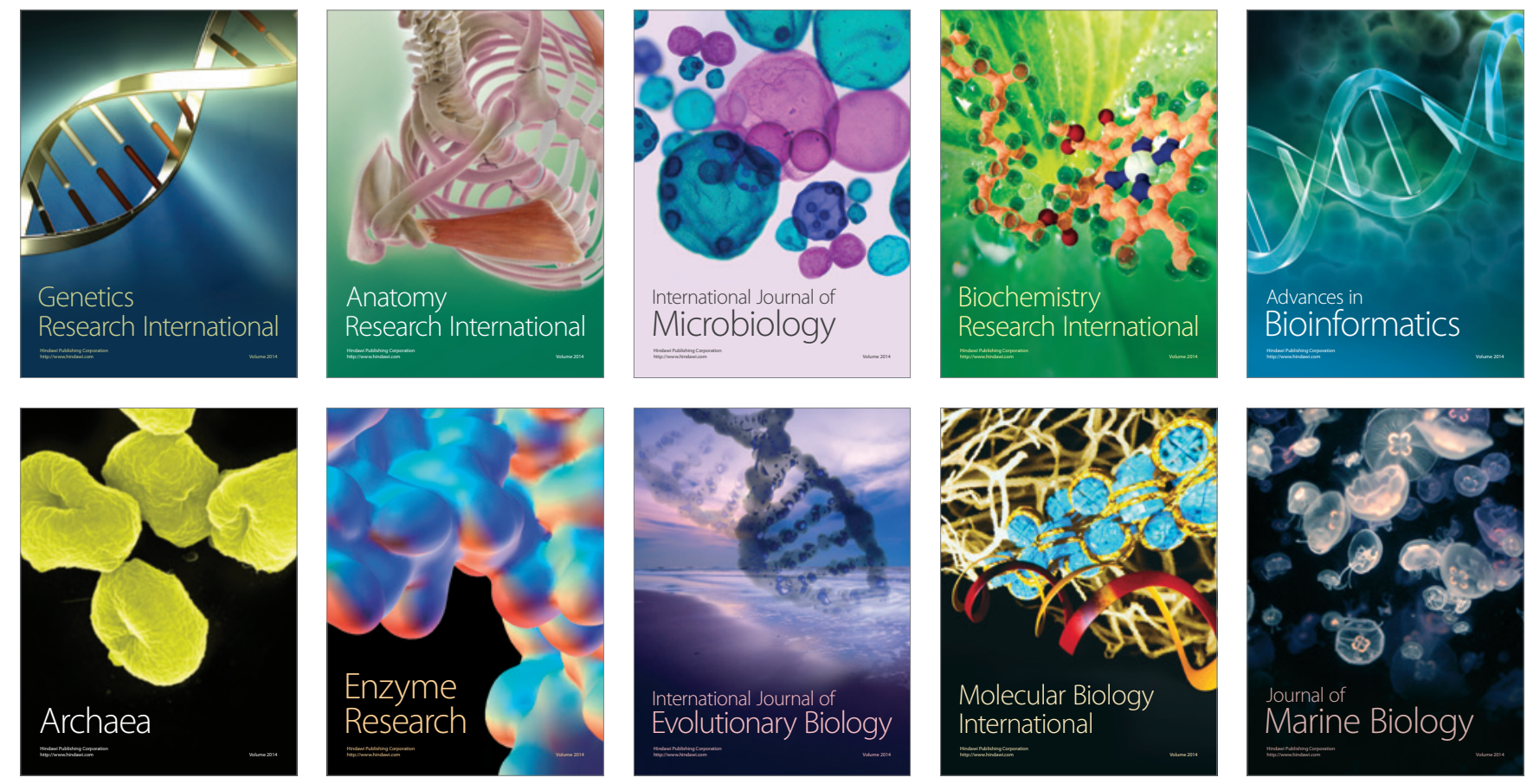